\title{
Energy savings of hybrid dew-point evaporative cooler and micro-channel separated heat pipe cooling systems for computer data centers
}

\author{
Yuting Liu ${ }^{\text {a }}$, Xu Yang ${ }^{a}$, Junming Li ${ }^{\text {a, }}{ }^{*}$, Xudong Zhao ${ }^{b}$ \\ ${ }^{a}$ Key Laboratory for Thermal Science and Power Engineering of Ministry of Education, Department of Energy and Power Engineering, Tsinghua University, \\ Beijing, 100084, China \\ ${ }^{\mathrm{b}}$ School of Engineering, University of Hull, HU6 7RX, UK
}

\section{A R T I C L E I N F O}

\section{Article history:}

Received 29 May 2018

Received in revised form 24 July 2018

Accepted 26 July 2018

Available online 14 August 2018

\section{Keywords:}

Hybrid cooling system

Micro-channel separated heat pipe

Dew-point evaporative cooler

CDCs

\begin{abstract}
A B S T R A C T
The world has entered the Age of Big Data with large data centers consuming large amounts of energy. $30 \%-50 \%$ of the energy delivered to a typical data center is consumed by the space cooling system. Dewpoint evaporative coolers and heat pipes both utilizing natural cold resources can significantly reduce these refrigeration costs. This paper presents two hybrid cooling systems combining dew-point evaporative coolers with heat pipes for computing and data center cooling systems. The energy-saving potentials of two these hybrid cooling systems were analysed through calculations with comparisons with a traditional vapour compression refrigeration system. The results show that the average annual coefficients of performance (COP) of the ideal hybrid refrigeration systems are 33 and 34 which leads to annual energy savings of nearly $90 \%$ compared with vapour compression refrigeration.
\end{abstract}

Crown Copyright $\odot 2018$ Published by Elsevier Ltd. All rights reserved.

\section{Introduction}

Computing and data centers (CDCs) with buildings, services and computing and data processing facilities (e.g. servers, computing telecommunication equipment, air conditioners and power equipment, [1]) have rapidly developed over the past 40 years. In 2010 , the total electrical energy used in CDCs was around $1.3 \%$ of the world's total energy consumption, with a rate of $1.4 \%$ in Europe and $1.5 \%$ in China [1-4]. Europe currently has 1148 data centers [5] that consume more than 100 TWh of electricity each year. In China, the CDC capacity reached $28.5 \mathrm{GW}$ in 2013 [3,6], with 549.6 TWh annual electrical consumption. The CDC capacity continues to expand globally and the CDC electrical energy consumption will continue to grow at an annual rate of $15-20 \%$ in the foreseeable future [7].

The Power Usage Effectiveness (PUE), which is defined as the ratio of the total energy used by $\mathrm{CDC}$ facilities to the energy delivered to the computing equipment, is about 1.9 in the USA, 2.53 in Europe and 2.5 in China [1-4]. This means that $40 \%-60 \%$ of the electricity delivered to CDCs is used for operating the service

\footnotetext{
* Corresponding author.

E-mail address: lijm@tsinghua.edu.cn (J. Li).
}

facilities (largely for air conditioning), so the CDC operations are very inefficient. Space cooling is a fundamental need of CDCs to remove the tremendous amount of heat dissipated by the IT equipment to keep an adequate space temperature which consumes $30 \%-40 \%$ of energy delivered to the CDCs [1-4]. Thus, CDCs need very efficient cooling systems.

The most common cooling equipment for CDCs is mechanical vapour compression air conditioners, which makes use of high grade energy (i.e., electricity) at relatively low efficiencies (i.e. Coefficients of Performance (COP) of 2-3), leading to an environmentally unfriendly operation.

Since CDCs operate continually every day of the year, natural cooling resources can be used to save energy. Natural cooling resources can be used by direct cooling and indirect cooling systems. Direct cooling systems bring outdoor air directly into the room, which may result in humidity problems and increased pollutants and dust in the CDCs. Indirect cooling systems separate the indoor and outdoor air streams with a heat exchanger such as an air-air heat exchanger or heat pipes, which ensure the humidity and cleanliness requirements of the indoor air.

Heat pipes are very effective heat transfer devices that can efficiently transmit heat over a long distance through a small area without additional power. Heat pipes can be divided into the integral and separated types. Separated heat pipes are much more 
mature and more widely used than integral heat pipes in CDC cooling systems. However, heat pipe cooling can only be used when the outdoor temperature is below the required temperature and need to be combined with other cooling systems, usually mechanical vapour compression cooling systems, to provide cooling throughout the year. Different kinds of heat pipe systems that have been proposed for CDC cooling systems are summarized in Table 1.

Although heat pipe-vapour compression compound cooling systems save much energy compared to simple mechanical vapour compression cooling systems, the electricity energy consumption is still large when the outdoor air temperature is high, and needs to be further reduced by new cooling methods.

Evaporative cooling can conserve energy and protect the environment by using water evaporation to efficiently absorb the heat [18]. The existing evaporative cooling systems can be classified into direct evaporative cooling (DEC) and indirect evaporative cooling (IEC) systems. Indirect evaporative cooling system, where the product air in dry channel and working air and water film in wet channel are separated by heat exchange plate, can lower the product air temperature without adding moisture to product air, so they are more suitable for air conditioning in more climates than DEC systems and, thus, are more widely used [19-21]. Many evaporative cooling systems have been used for $\mathrm{CDC}$ cooling like direct evaporative cooling system [22], indirect evaporative cooling with direct expansion refrigeration system [23], and indirect evaporative cooling with dew-point evaporative cooling system [24]. However, evaporative cooling systems are not widely used because of their relative low energy efficiencies, large volumes and restrictions on the supply air temperature [25]. A counter-flow corrugated plate dew-point evaporative cooler is described in this paper that gives higher cooling efficiencies (wet-bulb efficiency) and energy efficiency (COP) than ordinary indirect evaporative cooling by improving the design of the indirect evaporative cooling system. Experimental results show that the cooling efficiency can reach $125 \%$ and the COP can reach 43 for a $10 \mathrm{~kW}$ dew-point evaporative cooler. Thus, dew-point evaporative cooling has great potential for saving energy in CDC cooling. However, the dew-point evaporative cooler, as a standalone system with an air exhaust tube, can only supply air centrally, e.g. the upper air supply or the downside air supply, while the evaporators with the separated heat pipes can be distributed to each IT system to further improve the heat transfer efficiency.

The heat pipe and dew-point evaporative cooler are both energy efficient and environmentally friendly but the heat pipe can only be used when the outdoor temperature is below a certain temperature while the dew-point evaporative cooler can give high cooling efficiencies even with high outdoor temperatures. Therefore, a heat pipe-dew-point evaporative cooler hybrid cooling system is proposed and analysed here to satisfy the $\mathrm{CDC}$ cooling requirements and simultaneously save enormous amounts of energy.

This paper describes two hybrid cooling systems combining micro-channel separated heat pipes with dew-point evaporative coolers with the energy saving potentials of the two hybrid cooling systems analysed through calculations.

\section{CDC design requirement and operating conditions}

\section{1. $C D C$ indoor air requirements}

According to the Chinese $《$ Standard Specifications for Design of Electronic Information System Rooms $\rangle)($ GB 50174-2008) [26], data centers are classified into three levels based on their functions, significance and reliability. Generally, large data centers are classified into level A (extremely important) and B (important). The environmental specifications for level $A$ and $B$ data centers are shown in Table 2 . The following designs are based on the specifications listed in Table 2 [26].

The local air supplies are normally separated into cold and hot aisles in CDC cooling systems. Considering the improvement of the performance of IT equipment for the state-of-the art data center, the cold aisle temperature was assumed to be $23 \pm 1^{\circ} \mathrm{C}$, and the hot aisle temperature was set to be $35^{\circ} \mathrm{C}$ to save energy.

\subsection{CDC operating assumptions}

The CDC IT equipment is assumed to dissipate $5 \mathrm{~kW}$ per piece and $100 \mathrm{~kW}$ in total. Thus, the CDC is assumed to have:

$$
100 \mathrm{~kW} / 5 \mathrm{~kW}=20 \text { pieces }
$$

According to the Chinese $\langle$ Standard Specifications for Design of Electronic Information System Rooms $\rangle$ (GB 50174-2008), the floor area of $C D C$ room before the equipment is selected can be estimated as:

$$
A=K N
$$

where $\mathrm{K}$ is the floor area for each piece of equipment, usually $3.5-5.5 \mathrm{~m}^{2}$ and $\mathrm{N}$ is the number of computer systems in the room. The floor area for each computer system is set to $5 \mathrm{~m}^{2}$ in this study, so the total area of the CDC is $100 \mathrm{~m}^{2}$.

The thermal load coefficient of outside environment is assumed to be $0.15 \mathrm{~kW} / \mathrm{m}^{2}$, so the total thermal load from outside environment is $15 \mathrm{~kW}$ and the total thermal load that needs to be removed by cooling system of the CDC is $115 \mathrm{~kW}$, which is the base for

Table 2

Environmental specification for data centers.

\begin{tabular}{ll}
\hline- & A and B levels \\
\hline Temperature $/{ }^{\circ} \mathrm{C}$ & $23 \pm 1$ \\
Relative Humidity $/ \%$ & $40-50$ \\
Temperature variation rate $/\left({ }^{\circ} \mathrm{C} / \mathrm{h}\right)$ & $<5$, moisture condensation not allowed \\
\hline
\end{tabular}

Table 1

\begin{tabular}{|c|c|c|}
\hline Researcher & Heat Pipe System & Year \\
\hline Weber and Wyatt [8] & Integrated heat pipe system with a pressurized air duct & 2011 \\
\hline Xia et al. [9] & Separated heat pipe system with forced convection & 2008 \\
\hline Xia et al. [10] & Separated heat pipe system with natural convection & 2008 \\
\hline Suenaga and Ichimura [11] & Heat pipe-vapour compression one-piece air conditioner & 1986 \\
\hline Wang et al. [12] & Heat pipe-vapour compression compound air conditioner with additional heat exchanger & 2013 \\
\hline Han et al. [13] & Heat pipe-vapour compression compound air conditioner with three-way valve & 2013 \\
\hline Yan et al. [14], Ma et al. [15] & Heat pipe-vapour compression compound air conditioner driven by a liquid pump & 2015 \\
\hline Zhang et al. [16] & Mechanical refrigeration/loop heat pipe one-piece air conditioner based on a three-medium heat exchanger & 2015 \\
\hline Lee et al. [17] & Heat pipe-vapour compression compound air conditioner with four solenoid valves & 2006 \\
\hline
\end{tabular}

Recent heat pipe research for CDC cooling systems. 
designing the hybrid cooling system.

\section{Hybrid cooling system design}

Two different hybrid cooling systems with separated heat pipes and dew-point evaporative coolers were designed to satisfy the year round CDC cooling requirements with the designs shown in Figs. 1 and 2. The evaporators (2) of the separated heat pipes are distributed directly to the backs of the IT equipment (10) and are equipped with variable frequency fans to adjust the air volume according to the system operating conditions. A liquid pump (5) pumps liquid around the bypass in the liquid line of the heat pipe system when the outdoor temperature is very high; otherwise, the heat pipe works in natural circulation mode. Indoor air flows through the IT equipment (10) where it is heated by the IT equipment and then flows through the evaporators (2) on the back of the IT equipment where it is again cooled to the indoor air temperature. The evaporator layout is shown in Fig. 3. The dew-point evaporative cooler designs differ in the two systems with the specific operating modes for the two systems are listed in Tables 3 and 4.

System A: The heat pipe and the dew-point evaporative cooler can run independently or simultaneously. When the outdoor air temperature is below $12^{\circ} \mathrm{C}$, the system uses only the heat pipe.

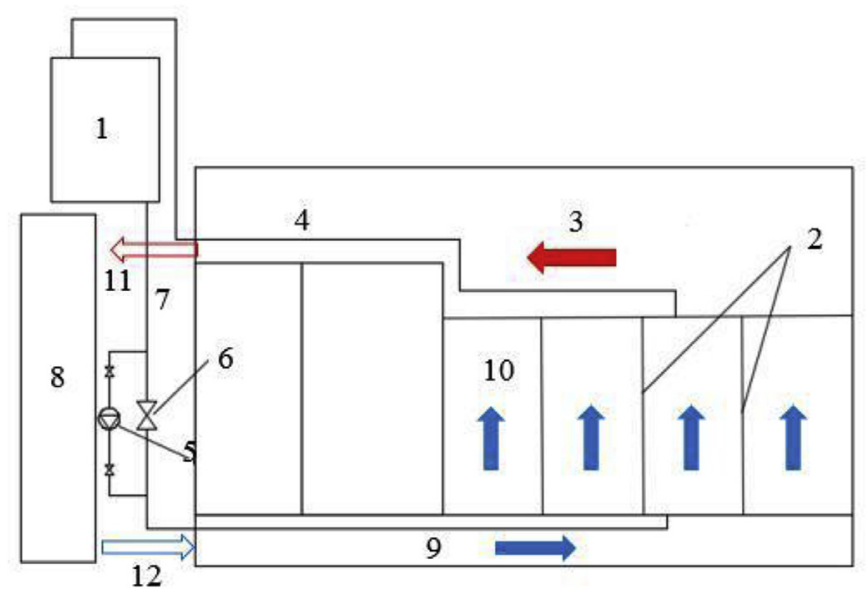

Fig. 1. System A 1 Heat pipe condenser section, 2 Heat pipe evaporator sections, 3 Return air duct, 4 vapour tube, 5 liquid pump. 6 bypass valve. 7 liquid tube, 8 dewpoint evaporative cooler, 9 underfloor air supply duct, 10 IT equipment, 11 exhaust air, 12 supply air from the dew-point evaporative cooler.

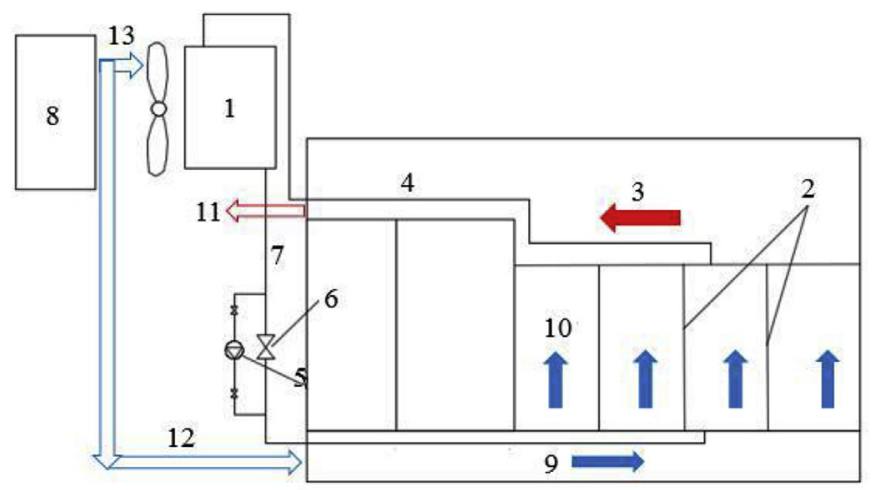

Fig. 2. System B 1 Heat pipe condenser section, 2 Heat pipe evaporator sections, 3 Return air duct, 4 vapour tube, 5 liquid pump. 6 bypass valve. 7 liquid tube, 8 dewpoint evaporative cooler, 9 underfloor air supply duct, 10 IT equipment, 11 exhaust air, 12 supply air from the dew-point evaporative cooler.

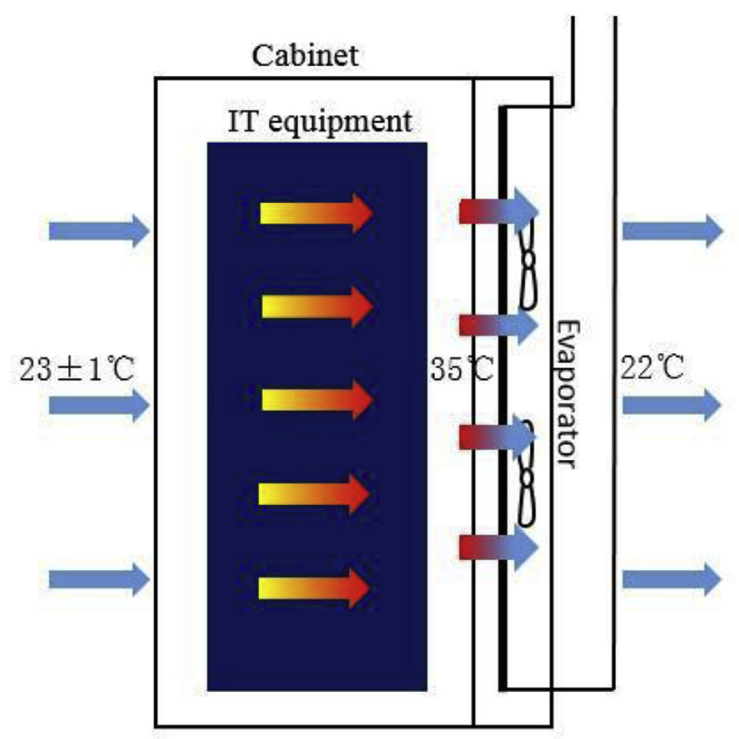

Fig. 3. Heat pipe evaporator layout.

Table 3

System A operating modes.

\begin{tabular}{ll}
\hline Outdoor air temperature $/{ }^{\circ} \mathrm{C}$ & Operating mode \\
\hline$\leq 12$ & Heat pipe mode \\
$12-18$ & Compound mode \\
$>18$ & Dew-point evaporative cooler mode \\
\hline
\end{tabular}

Table 4

System B operating modes.

\begin{tabular}{ll}
\hline Outdoor air temperature $/{ }^{\circ} \mathrm{C}$ & Operating mode \\
\hline$\leq 12$ & Heat pipe mode \\
$12-25$ & Cascade mode \\
$25-26$ & Compound and cascade mode \\
$\geq 27$ & Dew-point evaporative cooler mode \\
\hline
\end{tabular}

When the outdoor air temperature is between 12 and $18^{\circ} \mathrm{C}$, the heat pipe alone can no longer satisfy the cooling requirements, so the dew-point evaporative cooler is also run. The supply air from the dew-point evaporative cooler is delivered to the room through the bottom air duct (9). When the outdoor air temperature is above $18^{\circ} \mathrm{C}$, the heat pipe cannot work and only the dew-point evaporative cooler is used.

System B: When the outdoor air temperature is below $12^{\circ} \mathrm{C}$, only the heat pipe is used as in system $\mathrm{A}$. When the outdoor air temperature is between 12 and $25^{\circ} \mathrm{C}$, the heat pipe alone can no longer satisfy the cooling requirements, so supply air from the dewpoint evaporative cooler is used as the cooling air for the heat pipe condenser in the cascade mode. When the outdoor air temperature is between 25 and $26^{\circ} \mathrm{C}$, the cascade mode can no longer satisfy the cooling requirements, so part of the supply air from the dew-point evaporative cooler is delivered to the room through the bottom air duct for cooling. When the outdoor air temperature is over $27^{\circ} \mathrm{C}$, the heat pipe cannot work and only the dew-point evaporative cooler is used.

\section{Design of the micro-channel separated heat pipe}

The flow diagram for the separated heat pipe is shown in Fig. 4 with a liquid pump in the liquid tube to supplement the natural 


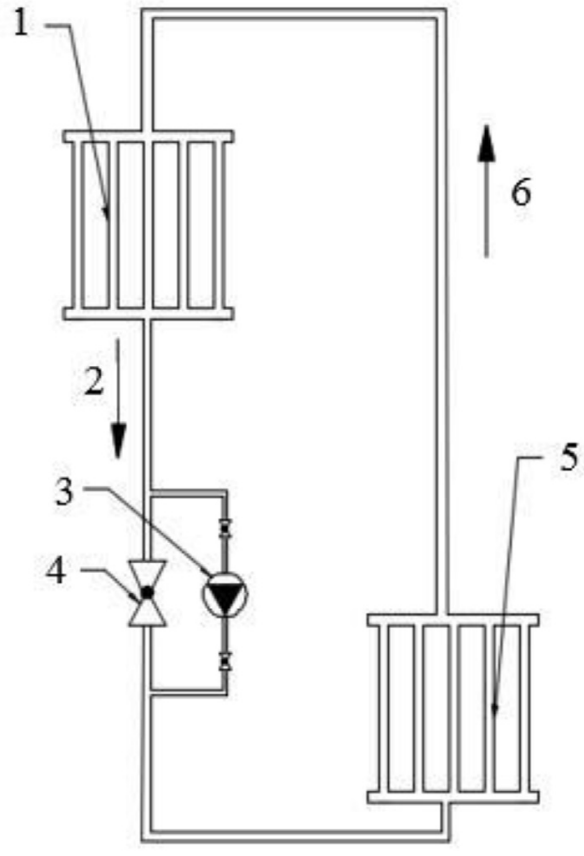

Fig. 4. Flow diagram for the separated heat pipe. 1. Condenser, 2. Liquid tube, 3. Liquid pump, 4. Bypass valve, 5. Evaporator, 6. Vapour tube.

convection flow when needed. When the temperature difference between the indoor and outdoor air is too large, the natural circulation mode will be changed to the circulation mode driven by the liquid pump to improve the cycle performance. The heat pipe was designed based on "ideal cycle" assumptions as follows:

(1) Only two-phase flow exists in the evaporator and condenser.

(2) The evaporation temperature is equal to the condensation temperature.

Table 5

Flat tube design parameters.

\begin{tabular}{lllllll}
\hline $\begin{array}{l}\text { Tube Tube } \\
\text { width thickness }\end{array}$ & $\begin{array}{l}\text { Channel } \\
\text { width } a \\
T_{\mathrm{d}} \\
(\mathrm{mm})\end{array}$ & $\begin{array}{l}D_{\mathrm{m}}(\mathrm{mm}) \\
(\mathrm{mm})\end{array}$ & $\begin{array}{l}\text { Channel } \\
\text { height } b \\
(\mathrm{~mm})\end{array}$ & $\begin{array}{l}\text { Channel } \\
\text { gap } T_{\mathrm{b}} \\
(\mathrm{mm})\end{array}$ & $\begin{array}{l}\text { Tube wall } \\
\text { thickness } \delta_{\mathrm{g}} \\
(\mathrm{mm})\end{array}$ & $\begin{array}{l}\text { Number } \\
\text { of } \\
\text { channels } \\
n\end{array}$ \\
\hline 16 & 1.4 & 0.65 & 0.9 & 0.36 & 0.25 & 16 \\
\hline
\end{tabular}

Table 6

Louvered fin design parameters.

\begin{tabular}{|c|c|c|c|c|c|c|c|}
\hline $\begin{array}{l}\text { Fin } \\
\text { width } F_{\mathrm{d}} \\
(\mathrm{mm})\end{array}$ & $\begin{array}{l}\text { Fin } \\
\text { height } H \\
(\mathrm{~mm})\end{array}$ & $\begin{array}{l}\text { Fin } \\
\text { thickness } \\
\delta_{\mathrm{f}}(\mathrm{mm})\end{array}$ & $\begin{array}{l}\text { Fin gap } \\
F_{\mathrm{p}} \\
(\mathrm{mm})\end{array}$ & $\begin{array}{l}\text { Louver } \\
\text { gap } L_{\mathrm{p}} \\
(\mathrm{mm})\end{array}$ & $\begin{array}{l}\text { Louver } \\
\text { angle } L_{\alpha} \\
\text { (o) }\end{array}$ & $\begin{array}{l}\text { Louver } \\
\text { length } L_{1} \\
(\mathrm{~mm})\end{array}$ & $\begin{array}{l}\text { Number } \\
\text { of louvers } \\
m\end{array}$ \\
\hline 16 & 8 & 0.09 & 1.25 & 1.2 & 30 & 3.8 & 19 \\
\hline
\end{tabular}

\subsection{Micro-channel heat exchanger size}

A micro-channel heat exchanger can increase the heat transfer coefficient and the heat transfer rate compared to conventional size heat exchangers. The sizes of the flat tube and the louvered fins for the evaporator and condenser in the heat pipe are shown in Tables 5 and 6 with a schematic of the micro-channel flat tube section shown in Fig. 5.

The air side heat exchange area for a single-row, micro-channel heat exchanger per unit length is:

$$
\begin{aligned}
A_{\mathrm{a} 0}= & (N-1)\left[2\left(T_{\mathrm{d}}-D_{\mathrm{m}}\right)\left(1-\frac{\delta_{\mathrm{f}}}{F_{\mathrm{p}}}\right)+2 \frac{F_{\mathrm{d}}}{F_{\mathrm{p}}} \sqrt{H^{2}+F_{\mathrm{p}}^{2}}\right]+\pi D_{\mathrm{m}} N \\
& +2\left(T_{\mathrm{d}}-D_{\mathrm{m}}\right)
\end{aligned}
$$

where $N$ is the number of flat tubes.

The refrigerant side heat exchange area for the single-row, micro-channel heat exchanger per unit length is:

$A_{r 0}=N \times n \times 2(a+b)$

The contact area between the air and the fin in the single-row, micro-channel heat exchanger per unit length is:

$A_{\mathrm{f} 0}=(N-1) \times \frac{2 F_{\mathrm{d}}}{F_{\mathrm{p}}} \sqrt{H^{2}+F_{\mathrm{p}}^{2}}$

\subsection{Condenser design}

The volumetric airflow rate and the combination with the dewpoint evaporative coolers will require five condensers with the heat load of each condenser $\left(Q_{c}\right)$ assumed to be $23 \mathrm{~kW} \mathrm{R134a} \mathrm{is} \mathrm{used} \mathrm{as}$ the refrigerant and the assumed design parameters are listed in Table 7. The air side heat transfer coefficient, $h_{\mathrm{a}, \mathrm{c}}$, is given by the correlation proposed by Kim and Bullard [27].

$h_{\mathrm{a}, \mathrm{c}}=\frac{j \rho_{\mathrm{a}}^{\mathrm{c}} u_{\mathrm{a}} c_{\mathrm{a}}^{\mathrm{c}}}{\operatorname{Pr}_{\mathrm{a}}^{\mathrm{c} 2 / 3}}$

where the Colburn $j$-factor is calculated as:

Table 7

Condenser design parameters.

\begin{tabular}{llll}
\hline $\begin{array}{l}\text { Condensation } \\
\text { temperature } t_{\mathrm{c}} \\
\left({ }^{\circ} \mathrm{C}\right)\end{array}$ & $\begin{array}{l}\text { Inlet air dry bulb } \\
\text { temperature } t_{1}^{\mathrm{c}}\left({ }^{\circ} \mathrm{C}\right)\end{array}$ & $\begin{array}{l}\text { Outlet air dry bulb } \\
\text { temperature } t_{2}^{\mathrm{c}}\left({ }^{\circ} \mathrm{C}\right)\end{array}$ & $\begin{array}{l}\text { Outdoor air } \\
\text { relative humidity } \\
(\%)\end{array}$ \\
\hline 20 & 10 & 15 & 40 \\
\hline
\end{tabular}

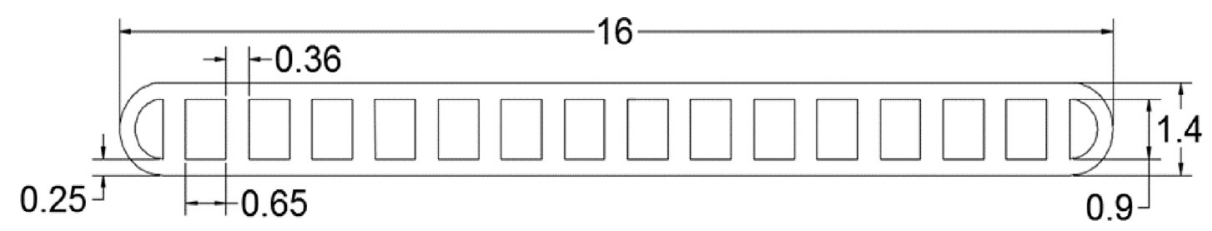

Fig. 5. Schematic of the micro-channel flat tube section used for heat pipe. 


$$
\begin{aligned}
j= & \operatorname{Re}_{\mathrm{Lp}}^{-0.487}\left(\frac{L_{\mathrm{a}}}{90}\right)^{0.257}\left(\frac{F_{p}}{L_{\mathrm{p}}}\right)^{-0.13}\left(\frac{H}{L_{\mathrm{p}}}\right)^{-0.29}\left(\frac{F_{\mathrm{d}}}{L_{\mathrm{p}}}\right)^{-0.235} \\
& \left(\frac{L_{\mathrm{l}}}{L_{\mathrm{p}}}\right)^{0.68}\left(\frac{T_{\mathrm{b}}}{L_{\mathrm{p}}}\right)^{-0.279}\left(\frac{\delta_{\mathrm{f}}}{L_{\mathrm{p}}}\right)^{-0.05}
\end{aligned}
$$

The Fanning friction factor is given by,

$$
f=\operatorname{Re}_{\mathrm{Lp}}^{-0.781}\left(\frac{L_{\mathrm{a}}}{90}\right)^{0.444}\left(\frac{F_{\mathrm{p}}}{L_{\mathrm{p}}}\right)^{-1.682}\left(\frac{H}{L_{\mathrm{p}}}\right)^{-1.22}\left(\frac{F_{\mathrm{d}}}{L_{\mathrm{p}}}\right)^{0.818}\left(\frac{L_{\mathrm{l}}}{L_{\mathrm{p}}}\right)^{1.97}
$$

where $\operatorname{Re}_{\mathrm{Lp}}$ is the air-side Reynolds number based on the louver pitch and is calculated as:

$\operatorname{Re}_{\mathrm{Lp}}=\frac{\rho_{\mathrm{a}}^{\mathrm{c}} u_{\mathrm{a}} L_{\mathrm{p}}}{\mu_{\mathrm{a}}^{\mathrm{c}}}$

The air velocity between the fins, $u_{\mathrm{a}}$, can be calculated based on the given face velocity of the air, $u$, and the heat exchanger design parameters:

$u_{\mathrm{a}}=\frac{u\left(H+D_{\mathrm{m}}\right) \times 2 F_{\mathrm{p}}}{H \times 2 F_{\mathrm{p}}-2 \sqrt{H^{2}+F_{\mathrm{p}}^{2}} \delta_{\mathrm{f}}}$

The surface effectiveness, $\eta_{a, c}$, and the fin efficiency, $\eta_{f}$, on the air side are given by: [28].

$\eta_{a, c}=1-\frac{A_{f o}}{A_{a o}}\left(1-\eta_{\mathrm{f}}\right)$

$\eta_{\mathrm{f}}=\frac{\operatorname{th}\left(m_{\mathrm{f}} l_{\mathrm{f}}\right)}{m_{\mathrm{f}} l_{\mathrm{f}}}$

where,

$m_{\mathrm{f}}=\sqrt{\frac{2 h_{\mathrm{a}, \mathrm{c}}}{\lambda_{\mathrm{f}} \delta_{\mathrm{f}}}\left(1+\frac{\delta_{\mathrm{f}}}{F_{\mathrm{d}}}\right)}$

$l_{\mathrm{f}}=\frac{H}{2}-\delta_{\mathrm{f}}$

The heat transfer calculation on the refrigerant side assumes that the refrigerant is two-phase in the condenser, but actually the refrigerant is superheated at the condenser inlet and is supercooled at the condenser outlet. Thus, the calculated heat transfer coefficient will be lower than the actual coefficient, but the difference is small and can be neglected. The refrigerant side condensation heat transfer coefficient, $h_{\mathrm{r}, \mathrm{c}}$, is calculated using the correlation proposed by Akers [29].

$h_{\mathrm{r}, \mathrm{c}}=0.0265 \operatorname{Re}_{e q}^{0.8} \operatorname{Pr}_{l}^{1 / 3} \frac{\lambda_{l}}{D_{\mathrm{h}}}$

where $\mathrm{Re}_{\mathrm{eq}}$ is the equivalent all liquid Reynolds number for the refrigerant calculated as:

$\operatorname{Re}_{\mathrm{eq}}=\frac{G_{\mathrm{eq}} D_{\mathrm{h}}}{\mu_{\mathrm{l}}}$

where Geq is the equivalent all liquid mass flow velocity of the refrigerant,
$G_{\mathrm{eq}}=G_{\mathrm{c}}\left[(1-x)+x\left(\frac{\rho_{\mathrm{l}}}{\rho_{\mathrm{g}}}\right)^{1 / 2}\right]$

$D_{\mathrm{h}}$ is the flat tube equivalent diameter,

$D_{\mathrm{h}}=\frac{2 a b}{a+b}$

Gc is the mass flow velocity of the refrigerant,

$G_{\mathrm{c}}=\frac{q_{\mathrm{r}, \mathrm{c}}}{N_{\mathrm{c}} \cdot a \cdot b \cdot n}$

$q_{\mathrm{r}, \mathrm{c}}$ is the mass flux of refrigerant calculated by,

$q_{\mathrm{r}, \mathrm{c}}=\frac{Q_{\mathrm{c}}}{h_{\mathrm{fg}}}$

where $Q_{c}$ is the heat load of each condenser and $h_{\mathrm{fg}}$ is latent heat of the refrigerant.

The surface effectiveness, $\eta_{r, c}$, and the fin efficiency, $\eta_{b}$, on the refrigerant side are calculated as: [30].

$\eta_{\mathrm{r}, \mathrm{c}}=1-\frac{N_{\mathrm{c}} A_{\mathrm{b} 0}}{A_{\mathrm{r} 0}}\left(1-\eta_{\mathrm{b}}\right)$

$\eta_{\mathrm{b}}=\frac{t h\left(m_{\mathrm{b}} l_{\mathrm{b}}\right)}{m_{\mathrm{b}} l_{\mathrm{b}}}$

where $A_{\mathrm{bo}}$ is the contact area between the refrigerant and the slices of a single flat tube,

$A_{b 0}=2(n-1) b$

$m_{\mathrm{b}}=\sqrt{\frac{2 h_{\mathrm{r}, \mathrm{c}}\left(L_{\mathrm{b}}+T_{\mathrm{b}}\right)}{\lambda_{\mathrm{al}} L_{\mathrm{b}} T_{\mathrm{b}}}}$

$l_{\mathrm{b}}=\frac{D_{\mathrm{m}}-2 \delta_{\mathrm{g}}}{2}$

The total heat transfer coefficient for the condenser can then be calculated as:

$K_{0, \mathrm{c}}=\frac{1}{\frac{A_{\mathrm{a} 0}}{A_{\mathrm{r} 0}} \frac{1}{\eta_{\mathrm{r}, c} h_{\mathrm{r}, \mathrm{c}}}+\frac{1}{\eta_{\mathrm{a}, \mathrm{c}} h_{\mathrm{a}, \mathrm{c}}}}$

Then, the total heat transfer area and the heat exchanger sizes can be calculated as:

$F_{0, c}=\frac{Q_{c}}{K_{0, c} \theta_{\mathrm{m}, c}}$

where $\theta_{m, c}$ is the heat transfer temperature difference given by:

$\theta_{m, c}=\frac{t_{2}^{\mathrm{c}}-t_{1}^{\mathrm{c}}}{\ln \left(\frac{t_{\mathrm{c}}-t_{1}^{\mathrm{c}}}{t_{\mathrm{c}}-t_{2}^{\mathrm{c}}}\right)}$

The final results for the condenser are shown in Table 8 .

\subsection{Evaporator design}

The evaporators are located on the back of the IT equipment as shown in Fig. 3. The design heat load of each evaporator is $5.75 \mathrm{~kW}$. The temperature of air distributed to the IT equipment is $23 \pm 1{ }^{\circ} \mathrm{C}$ 
Table 8

Condenser design results.

\begin{tabular}{|c|c|c|c|c|c|}
\hline $\begin{array}{l}\text { Heat load of each } \\
\text { condenser } Q_{c}(k W)\end{array}$ & $\begin{array}{l}\text { Total heat transfer } \\
\text { coefficient } K_{0 c}(\mathrm{~W} /(\mathrm{m} 2 \cdot \mathrm{K}))\end{array}$ & $\begin{array}{l}\text { Face velocity } \\
U(\mathrm{~m} / \mathrm{s})\end{array}$ & $\begin{array}{l}\text { Number of flat } \\
\text { tubes in } \\
\text { the condenser } \\
N_{\mathrm{c}}\end{array}$ & $\begin{array}{l}\text { Flat tube length } \\
\text { condenser } L_{\mathrm{c}}(\mathrm{mm})\end{array}$ & $\begin{array}{l}\text { Condenser } \\
\text { width }(\mathrm{mm})\end{array}$ \\
\hline 23 & 84.75 & 2.5 & 26 & 241 & 236.4 \\
\hline
\end{tabular}

Table 9

Evaporator design parameters.

\begin{tabular}{|c|c|c|c|}
\hline Evaporation temperature $t_{\mathrm{e}}\left({ }^{\circ} \mathrm{C}\right)$ & Inlet air dry bulb temperature $t_{1}^{\mathrm{e}}\left({ }^{\circ} \mathrm{C}\right)$ & Outlet air dry bulb temperature $t_{2}^{\mathrm{e}}\left({ }^{\circ} \mathrm{C}\right)$ & Indoor air relative humidity (\%) \\
\hline 20 & 35 & 22 & 45 \\
\hline
\end{tabular}

and increases to $35^{\circ} \mathrm{C}$ after flowing through the IT equipment. Then, the air flows through the heat pipe evaporator and is cooled to $22^{\circ} \mathrm{C}$ again. The evaporation temperature is set to $20^{\circ} \mathrm{C}$ to avoid moisture condensation. The design parameters are listed in Table 9.

The volumetric airflow rate through each evaporator is:

$V_{h, e}=\frac{Q_{e}}{\rho_{e, i n} c_{p, e, i n}\left(t_{2}^{e}-t_{1}^{e}\right)}$

The air-side heat transfer coefficient for the evaporator is calculated using Eqs. (6)-(14). The results for the air-side heat transfer are shown in Table 10.

The boiling heat transfer coefficient in the micro-channels is calculated using the correlation proposed by Sun and Mishima [30].

$h_{t p}=\frac{6 \mathrm{Re}_{\mathrm{lo}}^{1.05} \mathrm{Bo}^{0.54}}{\mathrm{We}_{l}^{0.191}\left(\frac{\rho_{\mathrm{l}}}{\rho_{\mathrm{g}}}\right)^{0.142}} \frac{\lambda_{\mathrm{l}}}{D_{\mathrm{h}}}$

where $\mathrm{We}_{l}$ is the Weber number for the liquid refrigerant defined as:

$\mathrm{We}_{\mathrm{l}}=\frac{G_{e}^{2} D_{\mathrm{h}}}{\sigma \rho_{l}}$

Bo is the Boiling number defined as:

$\mathrm{Bo}=\frac{q_{i}}{G_{e} h_{\mathrm{fg}}}$

$\operatorname{Re}_{l o}$ is the equivalent all liquid Reynolds number defined as:

$\operatorname{Re}_{\mathrm{lo}}=\frac{G_{e} D_{h}}{\mu_{l}}$

The total evaporator heat transfer coefficient is then defined as:
$K_{0, e}=\frac{1}{\frac{A_{\mathrm{a} 0} 0}{A_{r 0}} \frac{1}{\eta_{r, e} h_{t p}}+\frac{1}{\eta_{\mathrm{a}, e} h_{\mathrm{a}, e}}}$

The total outside heat transfer area is:

$F_{0, e}=\frac{Q_{e}}{K_{0, e} \theta_{\mathrm{m}, e}}$

The heat flux inside the tube, $q_{\mathrm{i}}$, can then be calculated and checked against the required heat transfer rate:

$q_{i}=\frac{A_{a 0}}{A_{r 0}} K_{0, e} \theta_{m, e}$

The final results for the evaporator are shown in Table 11.

\subsection{Pressure drop check}

The heat pipe condenser and evaporator designs are based on the assumption that the refrigerant flows with negligible pressure loss so the condensation temperature equals the evaporation temperature. The pressure drops should then be checked to verify that the design is reasonable.

The heat pipe evaporator was assumed to be $2.8 \mathrm{~m}$ below the condenser according to the CDC construction standard. The heat pipe heat transfer rate with natural circulation is influenced by the tube diameter of the rising vapour tube with a large diameter needed to work efficiently [31]. Thus, the diameters of the rising vapour tube and the falling liquid tube were both set to $25 \mathrm{~mm}$. The rising vapour tube is $3.1 \mathrm{~m}$ high and the falling liquid tube is $3 \mathrm{~m}$ high.

The equilibrium equation for the pressure drops for natural circulation is:

Table 10

Evaporator air-side results.

\begin{tabular}{|c|c|c|c|}
\hline Air-side heat transfer coefficient $h_{\mathrm{a}, \mathrm{e}}(\mathrm{W} /(\mathrm{m} 2 \cdot \mathrm{K}))$ & Air-side surface effectiveness $\eta_{\mathrm{a}, \mathrm{e}}$ & Refrigerant mass flux $q_{\mathrm{m}, \mathrm{e}}(\mathrm{kg} / \mathrm{s})$ & Refrigerant mass velocity $G_{\mathrm{e}}(\mathrm{kg} /(\mathrm{s} \cdot \mathrm{m} 2))$ \\
\hline 99.79 & 0.955 & 0.0315 & 187.23 \\
\hline
\end{tabular}

Table 11

Evaporator design results.

\begin{tabular}{|c|c|c|c|c|c|}
\hline $\begin{array}{l}\text { Heat load of each evaporator } Q_{e} \\
(\mathrm{~kW})\end{array}$ & $\begin{array}{l}\text { Total heat transfer coefficient } K_{0 \mathrm{e}}(\mathrm{W} / \\
(\mathrm{m} 2 \cdot \mathrm{K}))\end{array}$ & $\begin{array}{l}\text { Face velocity } u(\mathrm{~m} / \\
\mathrm{s})\end{array}$ & $\begin{array}{l}\text { Number of flat tubes } \\
N_{\mathrm{e}}\end{array}$ & $\begin{array}{l}\text { Flat tube length } L_{\mathrm{e}} \\
(\mathrm{mm})\end{array}$ & $\begin{array}{l}\text { Evaporator width } \\
(\mathrm{mm})\end{array}$ \\
\hline 5.75 & 75.76 & 2.5 & 18 & 160 & 161.2 \\
\hline
\end{tabular}




$$
\begin{aligned}
& \left(\Delta P_{\mathrm{g}}-\Delta P_{\mathrm{fr}}-\Delta P_{\mathrm{ac}}-\Delta P_{\text {local }}\right)_{c}+\left(\Delta P_{\mathrm{g}}-\Delta P_{\mathrm{fr}}-\Delta P_{\text {local }}\right)_{\mathrm{fa}}= \\
& \left(\Delta P_{\mathrm{g}}+\Delta P_{\mathrm{fr}}+\Delta P_{\mathrm{ac}}+\Delta P_{\text {local }}\right)_{e}+\left(\Delta P_{\mathrm{g}}+\Delta P_{\mathrm{fr}}+\Delta P_{\text {local }}\right)_{\mathrm{ri}}
\end{aligned}
$$

The pressure drops in the vapour tube and the liquid tube are calculated using the single-phase pressure drop equation:

$-\frac{d p}{d z}=\rho g \sin \theta+d p_{\mathrm{fr}}+d p_{\text {local }}$

The three terms on the right side represent the gravitational pressure drop, the friction pressure drop and the minor losses. The acceleration pressure drop is ignored because the density changes little for single-phase flow. The minor pressure drop includes the pressure drop for the refrigerant flow through the two elbows in the tube line. The liquid tube pressure drop includes the pressure drops in the liquid part and the vapour part. The height of liquid part can be calculated using equation (37). The pressure drops are then listed in Table 12.

The two-phase flow pressure drops in the evaporator and condenser are calculated as:

$$
\begin{aligned}
-\frac{d p}{d z}= & \left(\rho_{l}(1-\alpha)+\rho_{\mathrm{g}} \alpha\right) g \sin \theta+G^{2} \frac{d}{d z}\left[\frac{(1-x)^{2}}{\rho_{l}(1-\alpha)}+\frac{x^{2}}{\rho_{\mathrm{g}} \alpha}\right]+d p_{f r} \\
& +d p_{\text {local }}
\end{aligned}
$$

The three terms on the right represent the gravitational pressure drop, the acceleration pressure drop, the friction pressure drop and the minor losses. The void fraction, $\alpha$, is calculated using the Thom model [32]: proposed by Fridel [33]. The two-phase multiplier is given by:

$$
\Phi_{L 0}^{2}=E+\frac{3.24 X F}{\mathrm{Fr}^{0.045} \mathrm{We}^{0.035}}
$$

The parameters $E, F$, and $X$ are defined as:

$$
\begin{aligned}
& E=(1-x)^{2}+x^{2} \frac{\rho_{l}}{\rho_{\mathrm{g}}} \frac{f_{\mathrm{g} 0}}{f_{l 0}} \\
& F=x^{0.78}(1-x)^{0.24} \\
& X=\left(\frac{\rho_{l}}{\rho_{g}}\right)^{0.91}\left(\frac{\mu_{g}}{\mu_{l}}\right)^{0.19}\left(1-\frac{\mu_{g}}{\mu_{l}}\right)^{0.7}
\end{aligned}
$$

The Froude and Weber numbers are defined as:

$\mathrm{Fr}=\frac{G^{2}}{g D_{h} \rho_{t p}^{2}}$

$\mathrm{We}=\frac{G^{2} D_{\mathrm{h}}}{\rho_{\mathrm{tp}} \sigma}$

The two-phase mixture density is given by:

$\rho_{t p}=\left(\frac{x}{\rho_{\mathrm{g}}}+\frac{1-x}{\rho_{l}}\right)^{-1}$

The terms with subscripts 10 and g0 correspond to the frictional pressure gradients when all the mixture is either liquid or gas. $f_{\mathrm{g} 0}$ and $f_{10}$ are calculated using the Churchill correlation: [34].

$f=8\left[\left(\frac{8}{\operatorname{Re}}\right)^{12}+\left\{\left[2.457 \times \ln \left(\frac{1}{\left(\frac{7}{\operatorname{Re}}\right)^{0.9}+0.27 \varepsilon / D_{\mathrm{h}}}\right)\right]^{16}+\left(\frac{37530}{\operatorname{Re}}\right)^{16}\right\}^{-1.5}\right]^{1 / 12}$

$\alpha=\left(1+\left(\frac{1-x}{x}\right)\left(\frac{\rho_{\mathrm{g}}}{\rho_{l}}\right)^{0.89}\left(\frac{\mu_{l}}{\mu_{\mathrm{g}}}\right)^{0.18}\right)^{-1}$

The friction pressure drop is calculated using the correlation

\begin{tabular}{|c|c|c|c|c|c|}
\hline & Gravity pressure drop $\triangle P_{\mathrm{g}}(\mathrm{KPa})$ & Friction pressure drop $\triangle P_{\mathrm{fr}}(\mathrm{KPa})$ & Minor losses $\triangle P_{\text {local }}(\mathrm{KPa})$ & $\begin{array}{l}\text { Total } \\
\text { pressure } \\
\text { drop } \triangle P \\
(\mathrm{KPa})\end{array}$ & Fluid height in liquid pipe (m) \\
\hline Rising vapour tube & 0.934 & 0.154 & 0.045 & 1.033 & - \\
\hline Falling liquid tube & 35.83 & 0.009 & 0.001 & 35.830 & 2.98 \\
\hline
\end{tabular}

The calculated pressure drops in the evaporator and condenser are listed in Table 13. The results show that the assumption that the heat pipe condensing and evaporation temperatures are the same

\begin{tabular}{|c|c|c|c|c|}
\hline & Gravitational pressure drop $\triangle P_{\mathrm{g}}(\mathrm{KPa})$ & Frictional pressure drop $\triangle P_{\mathrm{fr}}(\mathrm{KPa})$ & Acceleration pressure drop $\triangle P_{\mathrm{ac}}(\mathrm{KPa})$ & Overall pressure drop $\triangle P(\mathrm{KPa})$ \\
\hline Evaporator & 0.146 & 5.983 & 0.355 & 6.484 \\
\hline Condenser & 0.220 & 26.856 & 1.619 & 28.256 \\
\hline
\end{tabular}
is reasonable.

The condensation temperature is then calculated after taking

Table 12

The calculation results of the pressure drop in rising and falling pipe.

Table 13

Evaporator and condenser pressure drops. 
into account the pressure drops with the change in the condensation temperature shown in Table 14.

\section{Dew-point evaporative cooler design}

The $10 \mathrm{~kW}$ dew-point cooler was designed based on numerical simulations of a dew-point evaporative cooler. The heat exchanger is made of corrugated plates to increase the heat and mass transfer surface area and the wet surface is covered with a porous fabric to improve the water diffusion and increase the contact area between the wet air and the water. The design parameters are listed in Table 15. The dew-point evaporative cooler includes the heat exchanger, supply fan, exhaust fan, circulation water pump, water distributor and water tank as shown in Fig. 6.

Tests have shown that the supply air temperature is below $18^{\circ} \mathrm{C}$, the cooling efficiency (Wet-bulb efficiencye) can reach $125 \%$ and the cooler COP can reach 31 for a $10 \mathrm{~kW}$ dew-point evaporative cooler for outdoor with a dry-bulb temperature of $38.2{ }^{\circ} \mathrm{C}$ and a wet-bulb temperature of $22.1^{\circ} \mathrm{C}$. The detailed experimental results which has not been published are shown in Table 16. The performance of dew-point evaporative cooler is influenced by the outdoor air humidity, so the dehumidification is needed in highhumidity weather to guarantee that the temperature and humidity of the supply air delivered to the room are satisfactory. According to the experimental and simulation results, the changes of dry-bulb temperature of supply air are minor with the verification of drybulb temperature of inlet air if the dew-point temperature of inlet air is constant for the dew-point evaporative cooler. The dewpoint temperature of air is influenced by humidity of air only, so the supply air temperature and cooling capacity of the dew-point evaporative cooler can be controlled by controlling the humidity of inlet air.

This paper focuses the energy savings of the two hybrid cooling systems, so the cooling by the single dew-point evaporative cooler is assumed to be the same as in experimental results for the two systems to simplify the calculations with the energy consumed by the dew-point evaporative coolers being a function of the number of dew-point evaporative coolers required by the system. The detailed parameters for the dew-point evaporative cooler used in the systems are shown in Table 17.

Table 14

Change in the condensing temperature due to the pressure drops.

\begin{tabular}{lll}
\hline & Condensation temperature $\left({ }^{\circ} \mathrm{C}\right)$ & Saturation pressure $(\mathrm{MPa})$ \\
\hline Assumed values & 20 \\
Values taking into account the pressure drops & 19.573 & 0.5717 \\
\hline
\end{tabular}

Table 15

Corrugated plate parameters.

\begin{tabular}{|c|c|c|c|c|c|c|}
\hline Channel length (mm) & Channel gap (mm) & Channel width (mm) & Dry channel number & Wet channel number & Plate thickness (mm) & Fabric thickness (mm) \\
\hline 1050 & 4.3 & 716 & 117 & 117 & 0.2 & 0.5 \\
\hline
\end{tabular}

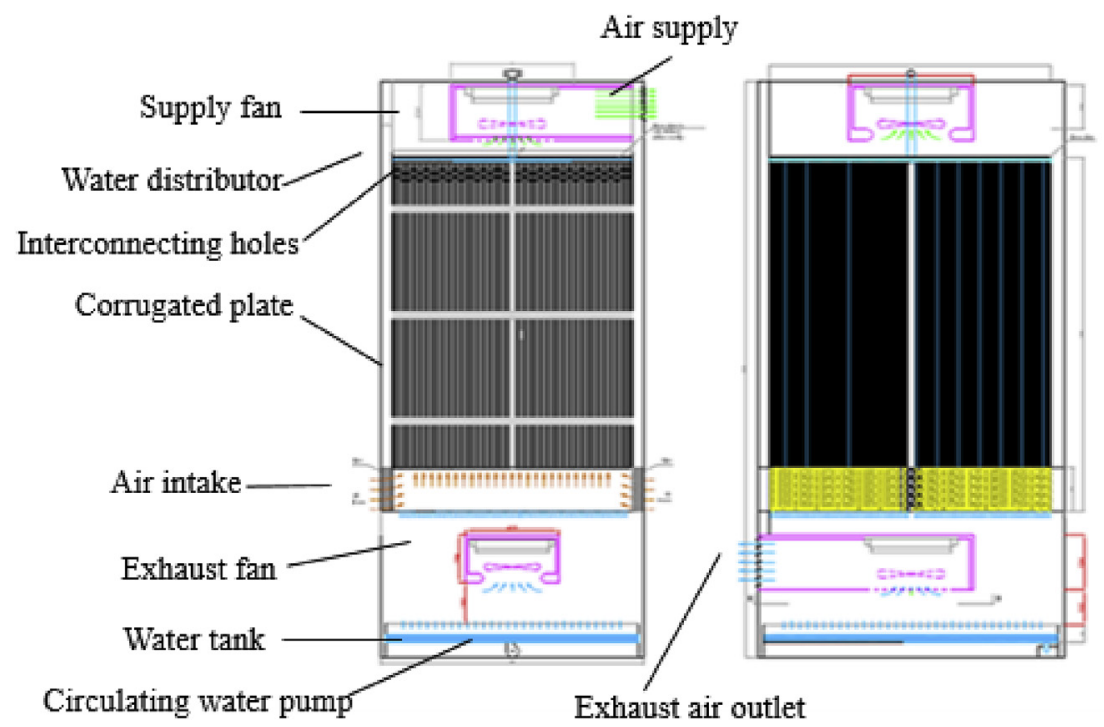

Fig. 6. Dew-point evaporative cooler schematic.

Table 16

Dew-point evaporative cooler experimental results.

\begin{tabular}{|c|c|c|c|c|c|c|c|c|}
\hline $\begin{array}{l}\text { Dry bulb temperature of } \\
\text { intake air }\left({ }^{\circ} \mathrm{C}\right)\end{array}$ & $\begin{array}{l}\text { Wet bulb temperature of } \\
\text { intake air }\left({ }^{\circ} \mathrm{C}\right)\end{array}$ & $\begin{array}{l}\text { Supply air } \\
\text { volume }\left(\mathrm{m}^{3} / \mathrm{h}\right)\end{array}$ & $\begin{array}{l}\text { Exhaust air } \\
\text { volume }\left(\mathrm{m}^{3} / \mathrm{h}\right)\end{array}$ & $\begin{array}{l}\text { Supply air dry bulb } \\
\text { temperature }\left({ }^{\circ} \mathrm{C}\right)\end{array}$ & $\begin{array}{l}\text { Cooling } \\
\text { capacity }(\mathrm{kW})\end{array}$ & $\begin{array}{l}\text { Power } \\
\text { consumption } \\
(\mathrm{kW})\end{array}$ & $\begin{array}{l}\text { Wet-bulb } \\
\text { efficiency }\end{array}$ & $\mathrm{COP}$ \\
\hline 38.2 & 22.1 & 3060 & 2378 & 18 & 10 & 0.32 & 125.5 & 31 \\
\hline
\end{tabular}


Table 17

Dew-point evaporative cooler parameters.

\begin{tabular}{|c|c|c|c|c|}
\hline $\begin{array}{l}\text { Total heat load } \\
(\mathrm{kW})\end{array}$ & $\begin{array}{l}\text { Heat load per dew-point evaporative } \\
\text { cooler }(\mathrm{kW})\end{array}$ & $\begin{array}{l}\text { Total number of dew-point evaporative } \\
\text { coolers }\end{array}$ & $\begin{array}{l}\text { Number of fans per dew-point evaporative } \\
\text { cooler }\end{array}$ & $\begin{array}{l}\text { Rated power per fan } \\
(\mathrm{kW})\end{array}$ \\
\hline 115 & 10 & 12 & 2 & 0.16 \\
\hline
\end{tabular}

\section{Energy-saving analyses of the hybrid cooling systems}

The dry-bulb temperature distribution in Beijing is shown in Fig. 7 [35]. There are on average $4091.4 \mathrm{~h}$ per year with dry-bulb temperatures below $12^{\circ} \mathrm{C}$ which is $46.7 \%$ of the time. There are then about $3539.4 \mathrm{~h}$ per year with dry-bulb temperatures over $18{ }^{\circ} \mathrm{C}$ which is $40.4 \%$ of the time. These numbers were then used to calculate the annual operating hours for each hybrid cooling system operating mode listed in Tables 3 and 4 with the results shown in Fig. 8.

The energy consumption in the heat pipe and the dew-point

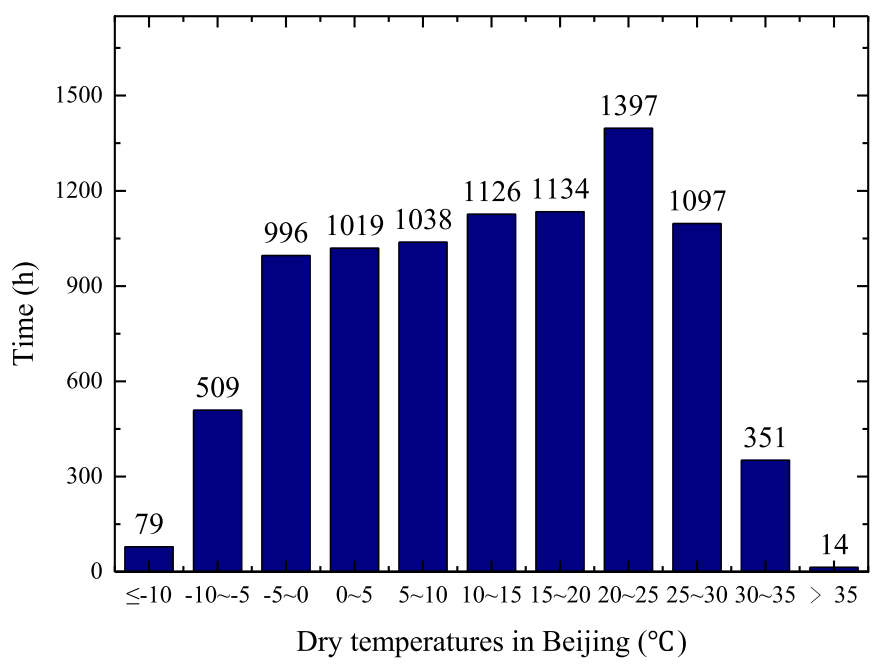

Fig. 7. Number of hours per year with these dry-bulb temperatures in Beijing. evaporative cooler systems is mainly the energy consumed by the fans. Thus, the system energy consumption is calculated as:

$P E=\frac{\Delta P V}{\eta_{1} \eta_{2}} M_{C}$

where $\Delta P$ is the air pressure drop, $V$ is the volumetric air flowrate, $\eta_{1}$ is the fan efficiency, $\eta_{2}$ is the mechanical efficiency, and $M_{C}$ is the motor capacity storage coefficient.

The air pressure drops across the heat pipe evaporator and condenser are calculated by:

$\Delta P=f \frac{A_{\mathrm{a} 0}}{A_{c 0}} \frac{\rho_{\mathrm{a}} u_{c}^{2}}{2}$

where the fanning friction factor, f, is calculated using Eq. (8) [29].

$A_{a 0}$ is the air side heat exchanger area, calculated using Eq. (3) $A_{c 0}$ is the minimum cross-sectional surface area

$u_{c}$ is the velocity at the minimum cross-sectional area

The energy consumption of the dew-point cooler is calculated based on the parameters in Table 17 and the number of dew-point evaporative coolers used in the hybrid cooling system. As shown in Table 17, the power consumed per dew-point evaporative cooler is $0.32 \mathrm{~kW}$.

The total energy consumption of the cooling systems is listed in Tables 18 and 19. The system COP of the heat pipe working alone can reach 42 with the annual average COP for hybrid system A being 33 and the for system $B$ being 34 . The total energy consumption rates for the two hybrid systems are compared with that of a conventional vapour compression refrigeration system in Table 20. The results show that the hybrid cooling systems

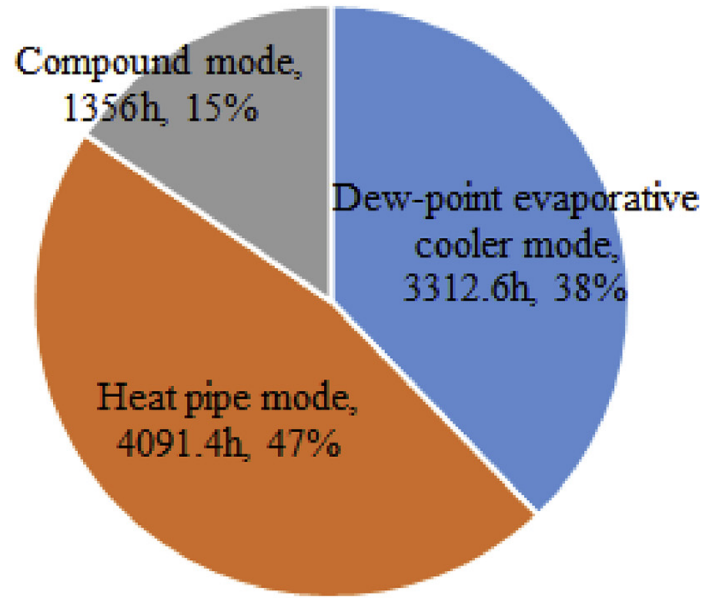

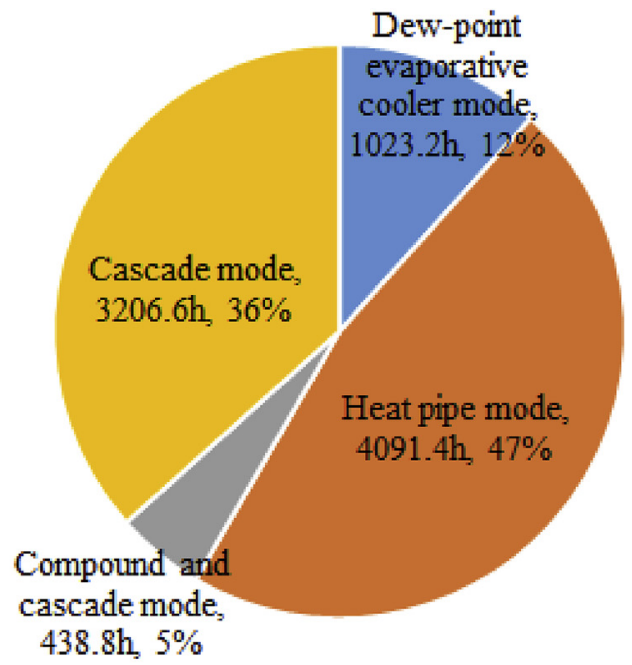

(2) System B

(1) System A

Fig. 8. Annual operating hours for the various modes. 
Table 18

Annual energy consumption for system A.

\begin{tabular}{|c|c|c|c|c|c|c|c|c|c|c|}
\hline Temperature $\left({ }^{\circ} \mathrm{C}\right)$ & $\leq 10$ & $10-11$ & $11-12$ & $12-13$ & $13-14$ & $14-15$ & $15-16$ & $16-17$ & $17-18$ & $>18$ \\
\hline Working time $(\mathrm{h})$ & 3641 & 225.2 & 225.2 & 225.2 & 225.2 & 225.2 & 226.8 & 226.8 & 226.8 & 3312.6 \\
\hline Total cooling capacity (kW) & 115 & 115 & 115 & 115 & 115 & 115 & 115 & 115 & 115 & 115 \\
\hline Cooling capacity of the heat pumps (kW) & 115 & 115 & 115 & 94.6 & 78.4 & 62.1 & 45.7 & 28.8 & 12.4 & 0 \\
\hline Cooling capacity of the dew-point evaporative coolers (kW) & 0 & 0 & 0 & 20.4 & 36.7 & 52.9 & 69.3 & 86.2 & 102.7 & 115 \\
\hline Fan power per heat pipe condenser (kW) & 0.43 & 0.43 & 0.80 & 0.61 & 0.61 & 0.61 & 0.61 & 0.61 & 0.68 & 0 \\
\hline Total heat pipe power consumption (kW) & 2.7 & 2.7 & 4.57 & 3.57 & 3.58 & 3.59 & 3.6 & 3.6 & 3.95 & 0 \\
\hline Total dew-point point cooler power consumption (kW) & 0 & 0 & 0 & 0.96 & 1.28 & 1.92 & 2.24 & 2.88 & 3.52 & 3.84 \\
\hline Total power consumption $(\mathrm{kW})$ & 2.7 & 2.7 & 4.57 & 4.53 & 4.86 & 5.51 & 5.84 & 6.48 & 7.47 & 3.84 \\
\hline Annual electricity consumption $(\mathrm{kW} \cdot \mathrm{h})$ & 9817 & 607 & 1028 & 1020 & 1094 & 1240 & 1323 & 1470 & 1694 & 12720 \\
\hline COP & 42 & 42 & 25 & 25 & 23 & 21 & 20 & 18 & 15 & 30 \\
\hline Total annual electricity consumption $(\mathrm{kW} \bullet \mathrm{h})$ & 32016 & & & & & & & & & \\
\hline Average COP & 33 & & & & & & & & & \\
\hline
\end{tabular}

Table 19

Annual energy consumption for system B.

\begin{tabular}{|c|c|c|c|c|c|c|c|c|c|c|}
\hline Temperature $\left({ }^{\circ} \mathrm{C}\right)$ & $\leq 11$ & $11-12$ & $12-15$ & $15-17$ & $17-19$ & $19-23$ & $23-24$ & $24-25$ & $25-27$ & $\geq 27$ \\
\hline Working time $(\mathrm{h})$ & 3866.2 & 225.2 & 675.6 & 453.6 & 453.6 & 1065 & 279.4 & 279.4 & 438.8 & 1023.2 \\
\hline Total cooling capacity $(\mathrm{kW})$ & 115 & 115 & 115 & 115 & 115 & 115 & 115 & 115 & 115 & 115 \\
\hline Cooling capacity of the heat pumps (kW) & 115 & 115 & 115 & 115 & 115 & 115 & 115 & 115 & $29-78$ & 0 \\
\hline Cooling capacity of the dew-point evaporative coolers (kW) & 0 & 0 & 10 & 20 & 30 & 40 & 60 & 80 & 115 & 115 \\
\hline Fan power per heat pipe condenser $(\mathrm{kW})$ & 0.43 & 0.80 & 0.43 & 0.61 & $0.43-0.68$ & 0.43 & 0.43 & 0.43 & 0.61 & 0 \\
\hline Total heat pipe power consumption (kW) & 2.7 & 4.6 & 2.7 & 3.6 & $2.7-3.95$ & 2.7 & 2.7 & 2.7 & 3.6 & 0 \\
\hline Total dew-point point cooler power consumption (kW) & 0 & 0 & 0.32 & 0.64 & 0.96 & 1.28 & 1.92 & 2.56 & $3.52-3.84$ & 3.84 \\
\hline Total power consumption $(\mathrm{kW})$ & 2.7 & 4.6 & 3 & 4.24 & $3.7-4.9$ & 3.98 & 4.6 & 5.3 & $7.1-7.4$ & 3.84 \\
\hline Annual electricity consumption $(\mathrm{kW} \cdot \mathrm{h})$ & 10424 & 1028 & 2038 & 1923 & 1943 & 4236 & 1290 & 1470 & 3191 & 3929 \\
\hline $\mathrm{COP}$ & 42 & 25 & 38 & 27 & $23-31$ & 28 & 24 & 22 & 15 & 30 \\
\hline Total annual electricity consumption $(\mathrm{kW} \bullet \mathrm{h})$ & 31470 & & & & & & & & & \\
\hline Annual Average COP & 34 & & & & & & & & & \\
\hline
\end{tabular}

Table 20

Comparison of annual energy consumption.

\begin{tabular}{|c|c|c|c|c|}
\hline Cooling system & Rated cooling capacity (kW) & Annual energy consumption $(\mathrm{kW} \cdot \mathrm{h})$ & Annual average COP & Energy saving proportion \\
\hline Vapour compression system & 115 & 305273 & 3.3 & 3.3 \\
\hline System A & 115 & 32016 & 33 & $89.5 \%$ \\
\hline System B & 115 & 31470 & 34 & $89.7 \%$ \\
\hline
\end{tabular}

described in this paper are much more efficient than conventional vapour compression refrigeration systems with and the energysaving ratios of nearly $90 \%$. Thus, the hybrid cooling systems can significantly reduce the $\mathrm{CDC}$ cooling cost.

System B is more efficient than system A, but system B is more complicated than system $A$ which will increase the operating and investment costs of system B. Thus, further life-cycle costs are needed to determine which CDC cooling system should be used.

In addition, a dehumidification system is needed when the dewpoint evaporative coolers work, so the actual energy consumption will be larger than the calculated results.

\section{Conclusions}

This paper describes data center cooling systems that effectively use natural cold sources to reduce the energy consumption in CDCs. Two hybrid cooling systems are given which combine dew-point evaporative coolers and micro-channel separated heat pipes which both provide significant energy savings. The micro-channel separated heat pipe is designed in detail and the dew-point evaporative cooler is chosen based on previous studies of dew-point evaporative coolers. Then, the energy consumption rates of both systems are calculated based on Beijing weather conditions. The conclusions are:
(1) Two kinds of hybrid cooling systems are described that both combine dew-point evaporative coolers and micro-channel separated heat pipes along with the system operating modes that vary with the outdoor air temperature.

(2) Micro-channel separated heat pipes are designed for the hybrid cooling systems based on the CDC design parameters. The pressure drops are calculated to check that the assumptions are reasonable.

(3) The dew-point evaporative cooler for the hybrid cooling system is chosen based on previous experimental results and numerical simulations, The detailed design parameters for the dew-point evaporative coolers are given in the paper.

(4) The energy consumption rates of the hybrid cooling systems are given for a typical year in Beijing and compared with the energy consumption of conventional vapour compression systems. The results show that the annual energy consumption is $32016 \mathrm{~kW} \mathrm{~h}$ and the average COP is 33 for system A. The annual energy consumption is $31470 \mathrm{kWh}$ and the average COP is 34 for system B. But the actual energy consumption is larger than calculation results considering the energy consumption of dehumidification system.

(5) Both hybrid cooling systems will use nearly 90\% less electricity than a conventional vapour compression system. Thus, the hybrid cooling systems combining dew-point 
evaporative coolers with micro-channel separated heat pipes have great potential for reducing CDC cooling costs.

\section{Acknowledgements}

This work was supported by the National Key R\&D Program of China (Grant No. 2016YFE0133300), the European Commission H20202 MSCA programme (for the EU H2020-MSCA-RISE-2016734340-DEW-COOL-4-CDC project) and the Royal Academy of Engineering (for the UK-CIAPPn415 project).

\section{Nomenclature}

A CDC floor area in Equation (2) $\left(\mathrm{m}^{2}\right)$

a Flat tube channel width ( $\mathrm{mm}$ )

$A_{\mathrm{a} 0} \quad$ Air side heat exchanger area in the single-row microchannel heat exchangers per unit length $\left(\mathrm{m}^{2}\right)$

$A_{\mathrm{f} 0} \quad$ Contact area between the air and the fins of the singlerow micro-channel heat exchangers per unit length $\left(\mathrm{m}^{2}\right)$

$A_{\mathrm{r} 0} \quad$ Refrigerant side heat exchanger area in the single-row micro-channel heat exchangers per unit length $\left(\mathrm{m}^{2}\right)$

$b \quad$ Flat tube channel height ( $\mathrm{mm})$

Bo Boiling number

$c_{\mathrm{p}} \quad$ Specific heat at constant pressure $(\mathrm{kJ} /(\mathrm{kg} \cdot \mathrm{K}))$

$c_{p, e, \text { in }} \quad$ Specific heat of the inlet air $(\mathrm{kJ} /(\mathrm{kg} \cdot \mathrm{K}))$

$D_{\mathrm{h}} \quad$ Flat tube equivalent diameter $(\mathrm{m})$

$D_{\mathrm{m}} \quad$ Flat tube thickness ( $\left.\mathrm{mm}\right)$

$f \quad$ Fanning friction factor

$F_{\mathrm{d}} \quad$ Fin width $(\mathrm{mm})$

$F_{0, c} \quad$ Total outside heat transfer area of the condenser $\left(\mathrm{m}^{2}\right)$

$F_{0, e} \quad$ Evaporator total outside heat transfer area $(\mathrm{m} 2)$

$F_{\mathrm{p}} \quad$ Fin gap $(\mathrm{mm})$

Fr $\quad$ Froude number

$G_{c}$ Mass flow velocity of the refrigerant $\left(\mathrm{kg} /\left(\mathrm{s} \cdot \mathrm{m}^{2}\right)\right)$

$G_{\text {eq }} \quad$ Equivalent all liquid mass flow velocity of the refrigerant $\left(\mathrm{kg} /\left(\mathrm{s} \cdot \mathrm{m}^{2}\right)\right)$

$G_{\mathrm{e}} \quad$ Refrigerant mass velocity $\left(\mathrm{kg} /\left(\mathrm{s} \cdot \mathrm{m}^{2}\right)\right)$

$H \quad$ Fin height $(\mathrm{mm})$

$h_{\mathrm{a}, \mathrm{c}} \quad$ Condenser air side heat transfer coefficient $(\mathrm{W} /(\mathrm{m} 2 \bullet \mathrm{K}))$

$h_{\mathrm{a}, \mathrm{e}} \quad$ Air-side heat transfer coefficient $\left(\mathrm{W} /\left(\mathrm{m}^{2} \cdot \mathrm{K}\right)\right)$

$h_{\mathrm{fg}} \quad$ Latent heat $(\mathrm{kJ} / \mathrm{kg})$

$h_{\mathrm{r}, \mathrm{c}} \quad$ Refrigerant side condensation heat transfer coefficient $(\mathrm{W} /(\mathrm{m} 2 \bullet \mathrm{K}))$

$h_{t p} \quad$ Boiling heat transfer coefficient $(\mathrm{W} /(\mathrm{m} 2 \cdot \mathrm{K}))$

j Colburn j factor

$K \quad$ Floor area per IT equipment piece $\left(\mathrm{m}^{2}\right)$

$K_{0, c} \quad$ Total condenser heat transfer coefficient $(\mathrm{W} /(\mathrm{m} 2 \cdot \mathrm{K}))$

$K_{0, e} \quad$ Total heat transfer coefficient $(\mathrm{W} /(\mathrm{m} 2 \cdot \mathrm{K}))$

$L_{\mathrm{c}} \quad$ Flat tube length in the condenser $(\mathrm{m})$

$L_{\mathrm{e}} \quad$ Flat tube length in the evaporator (m)

$L_{\mathrm{p}} \quad$ Louver gap $(\mathrm{mm})$

$L_{\alpha} \quad$ Louver angle $\left({ }^{\circ}\right)$

$L_{1} \quad$ Louver length $(\mathrm{mm})$

$m \quad$ Louver number

$M_{\mathrm{C}} \quad$ Motor capacity storage coefficient

$n \quad$ Flat tube channel number

$N \quad$ Number of IT pieces in the CDC

$N_{\mathrm{c}} \quad$ Number of flat tubes in the condenser

$N_{\mathrm{e}} \quad$ Number of flat tubes in the evaporator

$N_{\mathrm{f}} \quad$ Number of flat tubes ( $\mathrm{mm}$ )

$\triangle P_{\text {local }} \quad$ Minor losses pressure drop (KPa)

$\triangle P \quad$ Total pressure drop (KPa)

$\triangle P_{\mathrm{ac}} \quad$ Acceleration pressure drop $(\mathrm{KPa})$ $\triangle P_{\mathrm{fr}} \quad$ Friction pressure drop (KPa)

$\triangle P_{\mathrm{g}} \quad$ Gravitational pressure drop (KPa)

$P E \quad$ Cooling system energy consumption (kW)

$\mathrm{Pr}_{1} \quad$ Liquid phase Prandtl number

$Q_{c} \quad$ Heat load for each condenser $(\mathrm{kW})$

$Q_{e} \quad$ Heat load of each evaporator $(\mathrm{kW})$

$q_{i} \quad$ Evaporator refrigerant side heat flux

$q_{\mathrm{m}, \mathrm{c}} \quad$ Refrigerant mass flux (kg/s)

$q_{\mathrm{m}, \mathrm{e}} \quad$ Refrigerant mass flux $\mathrm{kg} / \mathrm{s}$ )

$\mathrm{Re}_{\mathrm{eq}} \quad$ Equivalent all liquid Reynolds number in the condenser

$\mathrm{Re}_{\mathrm{lo}} \quad$ Reynolds number for the liquid phase

$T_{\mathrm{b}} \quad$ Flat tube channel gap ( $\mathrm{mm}$ )

$t_{\mathrm{c}} \quad$ Condensation temperature $\left({ }^{\circ} \mathrm{C}\right)$

$T_{\mathrm{d}} \quad$ Flat tube width (mm)

$t_{\mathrm{e}} \quad$ Evaporation temperature $\left({ }^{\circ} \mathrm{C}\right)$

$t_{1}^{\mathrm{c}} \quad$ Condenser inlet air dry-bulb temperature $\left({ }^{\circ} \mathrm{C}\right)$

$t_{2}^{\mathrm{C}} \quad$ Condenser outlet air dry-bulb temperature $\left({ }^{\circ} \mathrm{C}\right)$

$t_{1}^{\mathrm{e}} \quad$ Evaporator inlet dry-bulb temperature $\left({ }^{\circ} \mathrm{C}\right)$

$t_{2}^{\mathrm{e}} \quad$ Evaporator outlet dry-bulb temperature $\left({ }^{\circ} \mathrm{C}\right)$

$u_{\mathrm{a}} \quad$ Air velocity among the fins $(\mathrm{m} / \mathrm{s})$

$u \quad$ Face velocity $(\mathrm{m} / \mathrm{s})$

$V_{h, e} \quad$ Evaporator volumetric air flowrate $\left(\mathrm{m}^{3}\right)$

$\mathrm{We}_{l} \quad$ Weber number for the liquid phase

$x$ Vapour fraction

\section{Greek symbols}

$\alpha \quad$ Void fraction

$\delta_{\mathrm{g}} \quad$ Flat tube wall thickness $(\mathrm{mm})$

$\delta_{\mathrm{f}} \quad$ Fin thickness ( $\mathrm{mm}$ )

$\varepsilon \quad$ Roughness of the inner tube surface ( $\mathrm{m}$ )

$\eta_{a, c} \quad$ Surface effectiveness of the air side of the condenser

$\eta_{a, e} \quad$ Evaporator air-side surface effectiveness

$\eta_{b} \quad$ Refrigerant side fin efficiency

$\eta_{f} \quad$ Air side fin efficiency

$\eta_{r, c} \quad$ Surface effectiveness of the refrigerant side of the condenser

$\eta_{r, e} \quad$ Evaporator refrigerant side surface effectiveness

$\eta_{1} \quad$ Fan efficiency

$\eta_{2} \quad$ Mechanical efficiency

$\theta_{m, c} \quad$ Heat transfer temperature difference $(\mathrm{K})$

$\lambda_{a l} \quad$ Thermal conductivity of aluminum $(\mathrm{W} /(\mathrm{m} \cdot \mathrm{K}))$

$\mu_{g} \quad$ Gas viscosity $(\mathrm{kg} / \mathrm{m} \bullet \mathrm{s})$

$\mu_{l} \quad$ Liquid viscosity $(\mathrm{kg} / \mathrm{m} \bullet \mathrm{s})$

$\rho_{\text {e.in }} \quad$ Inlet air density

$\rho_{g} \quad$ Gas refrigerant density $\left(\mathrm{kg} / \mathrm{m}^{3}\right)$

$\rho_{l} \quad$ Liquid refrigerant density $\left(\mathrm{kg} / \mathrm{m}^{3}\right)$

$\rho_{t p} \quad$ Two-phase mixture density

$\sigma \quad$ Surface tension (N/m)

$\Phi_{\text {Lo }}^{2} \quad$ Two-phase multiplier for the frictional pressure drop

Superscripts

c condenser

e evaporator

\section{Subscripts}

a air

ac acceleration

c condenser

e evaporator

eq equivalent

fa falling

fr frictional

g gravity 
g0

i

in

1

10

0

r

ri

tp

All mixture assumed to be vapour
internal surface
inlet
liquid phase
All mixture assumed to be liquid
outside surface
refrigerant
rising
two phase

\section{References}

[1] Renewable Energy Unit. The European code of conduct on data centre energy efficiency. Institute for Energy, Directorate-general Joint Research Centre. European Commission; 2015., Version 3.0. .

[2] Digital Realty Trust Inc. Europe campos survey results. Jan. 2013.

[3] China Data Centre Industry Development Alliance. Development plan for national green data centre in China. 18th March 2015.

[4] Berge MVD, Costa GD, Jarus M, Oleksiak A, Piatek W, Volk E. Modeling data center building blocks for energy-efficiency and thermal simulations. 2014.

[5] http://www.datacentermap.com/western-europe/, accessed on 17/07/2018.

[6] Li T. In-depth analysis of 2013 data centre efficiency situation. World Power Supp 2013;6:7-8.

[7] Brunschwiler T, Smith B, Ruetsche E, Michel B. Toward zero-emission data centers through direct reuse of thermal energy. IBM J Res Dev 2009;53(3). 11: 1-:3.

[8] Weber RM, Wyatt WG. Heat removal system for computer rooms. 2011. US.

[9] Xia Jianjun, Li Zhen, Jiang Yi, Zhao Yong, Qingfan Wei. A kind of forced convection separated heat pipe for heat removal of machine room. $\mathrm{CN}$ 101122413A. 2008 [in Chinese].

[10] Xia Jianjun, Li Zhen, Jiang Yi, Zhao Yong, Qingfan Wei. A kind of natural convection separated heat pipe for heat removal of machine room. CN201093659A. 2008 [in Chinese].

[11] Suenaga T, Ichimura M. Air-cooled packaged air conditioner utilizing thermosyphon system. Trans SHASEJ 1986;60(12):45-52.

[12] Wang T, Wang G, Wang M, Wang J, Zhao S, Liu H, et al. Design and study of composite refrigeration system with heat pipe used in high-performance computer. Cryogen Supercond 2013;41(8):63-6.

[13] Han L, Shi W, Wang B, Zhang P, Li X. Development of an integrated air conditioner with thermosyphon and the application in mobile phone base station. Int J Refrig 2013;36(1):58-69.

[14] Yan G, Feng Y, Peng L. Experimental analysis of a novel cooling system driven by liquid refrigerant pump and vapor compressor. Int J Refrig 2015;49:11-8.

[15] Ma Y, Ma G, Zhang S, Xu S. Experimental investigation on a novel integrated system of vapor compression and pump-driven two phase loop for energy saving in data centers cooling. Energy Convers Manag 2015;106:194-200.
[16] Zhang H, Shao S, Xu H, Zou H, Tang M, Tian C. Numerical investigation on fintube three-fluid heat exchanger for hybrid source HVAC\&R systems. App Therm Eng 2016;95:157-64.

[17] Lee S, Song J, Kim Y, Chung J. Experimental study on a novel hybrid cooler for the cooling of telecommunication equipments. ChemInform 2006;26(24) $116-25$.

[18] Xu P, Ma X, Diallo TMO, Zhao X, Fancey K, Li D, et al. Numerical investigation of the energy performance of a guideless irregular heat and mass exchanger with corrugated heat transfer surface for dew point cooling. Energy 2016;109: 803-17.

[19] Ham SW, Jeong JW. DPHX (dew point evaporative heat exchanger): system design and performance analysis. Energy 2016;101:132-45.

[20] Duan Z, Zhao X, Li J. Design, fabrication and performance evaluation of a compact regenerative evaporative cooler: towards low energy cooling for buildings. Energy 2017;140.

[21] Xu P, Ma X, Zhao X, Fancey K, Yan J. Experimental investigation of a super performance dew point air cooler. Appl Energy 2017;203:761-77.

[22] Huang Xiang, Fan Kun, Song Jiaojiao, et al. Discussion on application the data center of evaporative cooling technology. Refrig Air Cond 2013;13(8):16-22.

[23] Huang Xiang, Han Zhenglin, Song Jiaojiao, Jianli Zhe. Application of evaporative cooling air conditioning in data center at home and abroad. Chin J Refrig Technol 2015;35(2):5-9.

[24] He Huaming, Jiang Xiaoqiang, Chen Mingsong, Huang Hualing. Study on the application of dew-point evaporation cooling technology for data center. In: Proceedings of the 2016 academic annual conference of fujian institute of refrigeration; 2016 [in Chinese].

[25] Lee J, Choi BS, Lee DY. Comparison of configurations for a compact regenerative evaporative cooler. Int J Heat Mass Tran 2013;65(5):192-8.

[26] GB 50174-2008. Standard specifications for design of Electronic information system room. 2008 [in Chinese].

[27] Kim MH, Bullard CW. Air-side thermal hydraulic performance of multilouvered fin aluminum heat exchangers. Int J Refrig 2002;25(3):390-400.

[28] Lee HS. Compact Heat Exchang 2010;27(2):460-70.

[29] Akers WW, Rosson HF. Condensation inside a horizontal tube. In: Chemical engineering program symposium series, vol. 56; 1960. p. 145-9.

[30] Sun L, Mishima K. An evaluation of prediction methods for saturated flow boiling heat transfer in mini-channels. Int J Heat Mass Tran 2009;52(23-24): 5323-9.

[31] Zhang P, Wang B, Shi W, Han L, Li X. Modeling and performance analysis of a two-phase thermosyphon loop with partially/fully liquid-filled downcomer. Int J Refrig 2015;58:172-85.

[32] Thom JRS. Prediction of pressure drop during forced circulation boiling of water. Int J Heat Mass Tran 1948;7(7):709-24.

[33] Friedel L. Improved friction pressure drop correlations for horizontal and vertical two-phase pipe flow. 1979.

[34] Churchill SW. Friction-factor equation spans all fluid-flow regimes. 1977.

[35] Guan Yong, Chao Chen, Xu Lei, et al. Application research of using natural cooling technology to air-conditioning system for the telecommunication rooms. Refrig Air Cond 2010;10(5):85-9. 